\title{
Calcium Response to Retinohypothalamic Tract Synaptic Transmission in Suprachiasmatic Nucleus Neurons
}

\author{
Robert P. Irwin and Charles N. Allen \\ Center for Research on Occupational and Environmental Toxicology, Oregon Health \& Science University, Portland, Oregon 97239
}

Glutamate released from retinohypothalamic tract (RHT) synapses with suprachiasmatic nucleus (SCN) neurons induces phase changes in the circadian clock presumably by using $\mathrm{Ca}^{2+}$ as a second messenger. We used electrophysiological and $\mathrm{Ca}^{2+}$ imaging techniques to simultaneously record changes in the membrane potential and intracellular calcium concentration $\left(\left[\mathrm{Ca}^{2+}\right]_{\mathrm{i}}\right)$ in SCN neurons after stimulation of the RHT at physiologically relevant frequencies. Stimulation of the RHT sufficient to generate an EPSP did not produce detectable changes in $\left[\mathrm{Ca}^{2+}\right]_{\mathrm{i}}$, whereas EPSP-induced action potentials evoked an increase in $\left[\mathrm{Ca}^{2+}\right]_{\mathrm{i}}$, suggesting that the change in postsynaptic somatic $\left[\mathrm{Ca}^{2+}\right]_{\mathrm{i}}$ produced by synaptically activated glutamate receptors was the result of membrane depolarization activating voltage-dependent $\mathrm{Ca}^{2+}$ channels. The magnitude of the $\mathrm{Ca}^{2+}$ response was dependent on the RHT stimulation frequency and duration, and on the SCN neuron action potential frequency. Membrane depolarization-induced changes in $\left[\mathrm{Ca}^{2+}\right]_{\mathrm{i}}$ were larger and decayed more quickly in the dendrites than in the soma and were attenuated by nimodipine, suggesting a compartmentalization of $\mathrm{Ca}^{2+}$ signaling and a contribution of L-type $\mathrm{Ca}^{2+}$ channels.

RHT stimulation at frequencies that mimicked the output of light-sensitive retinal ganglion cells (RGCs) evoked $\left[\mathrm{Ca}^{2+}\right]_{\mathrm{i}}$ transients in SCN neurons via membrane depolarization and activation of voltage-dependent $\mathrm{Ca}^{2+}$ channels. These data suggest that for $\mathrm{Ca}^{2+}$ to induce phase advances or delays, light-induced signaling from RGCs must augment the underlying oscillatory somatic $\left[\mathrm{Ca}^{2+}\right]_{\mathrm{i}}$ by evoking postsynaptic action potentials in SCN neurons during a period of slow spontaneous firing such as occurs during nighttime.

Key words: circadian rhythm; suprachiasmatic nucleus; action potential; retinal ganglion cells; synaptic transmission; calcium

\section{Introduction}

The suprachiasmatic nucleus (SCN) of the hypothalamus contains an endogenous pacemaker that regulates circadian rhythms (Moore and Eichler, 1972; Stephan and Zucker, 1972; Inouye and Kawamura, 1979). Mammals have evolved systems that entrain the circadian clock to environmental cues such as the light/dark cycle (DeCoursey et al., 1997; Ouyang et al., 1998), in which light is the temporal signal of greatest importance. Light can shift the circadian clock, producing phase delays early in the night, phase advances late in the night, and no changes during the day. Photic entrainment is mediated by light-sensitive retinal ganglion cells projecting axons via the retinohypothalamic tract (RHT) to synapse on SCN neurons (Moore et al., 1995; Pu, 1999; Berson et al., 2002; Warren et al., 2003). The frequency and duration of action potentials fired by the light-sensitive retinal ganglion cells is directly related to the light intensity (Berson et al., 2002; Warren et al., 2003; Tu et al., 2005).

Glutamate is the primary neurotransmitter released from synapses between RHT axon terminals and SCN neurons (Cahill and Menaker, 1989; Colwell and Menaker, 1992; Castel et al., 1993;

\footnotetext{
Received April 23, 2007; revised Aug. 16, 2007; accepted Sept. 12, 2007.

This work was supported by National Institute of Mental Health Grant MH 70922 (C.N.A.).

Correspondence should be addressed to Dr. Robert P. Irwin, Center for Research on Occupational and Environmental Toxicology, Oregon Health \& Science University, L-606, 3181 Southwest Sam Jackson Park Road, Portland, OR 97239. E-mail: irwinr@ohsu.edu.

DOI:10.1523/JNEUROSCI.1840-07.2007

Copyright $\odot 2007$ Society for Neuroscience $\quad$ 0270-6474/07/2711748-10\$15.00/0
}

Kim and Dudek, 1993; Ding et al., 1994; Jiang et al., 1997). Synaptically released glutamate activates both AMPA and NMDA receptors, and activation of either receptor can phase-shift the circadian clock (Colwell and Menaker, 1992; Kim and Dudek, 1993; Jiang et al., 1997; Pennartz et al., 2001). Similar to lightinduced phase changes, glutamate receptor activation early in the night phase delays the circadian clock, whereas late in the circadian, night phase advances the clock (Ding et al., 1994; Shirakawa and Moore, 1994).

Activating either AMPA or NMDA receptors will increase $\left[\mathrm{Ca}^{2+}\right]_{\mathrm{i}}$ in SCN neurons during both the day and the night (Colwell, 2001; Michel et al., 2002; Ikeda et al., 2003a,b). However, NMDA increases the $\left[\mathrm{Ca}^{2+}\right]_{\mathrm{i}}$ more during the night [Zeitgeber time (ZT) 14-18] than during the day (ZT 2-6), and a component $(\sim 50 \%)$ of the NMDA-induced $\mathrm{Ca}^{2+}$ increase is mediated via voltage-gated $\mathrm{Ca}^{2+}$ currents (Colwell, 2001). The circadian clock regulates the NMDA receptor activity in the SCN with larger NMDA-activated currents recorded during the subjective night (Pennartz et al., 2001). In contrast, $\mathrm{Ca}^{2+}$ transients produced by membrane depolarization (high K or AMPA) showed no day-night difference (Colwell, 2001; Ikeda et al., 2003a). In addition, $\mathrm{a} \mathrm{Ca}^{2+}$ flux is required for Per1 and Per2 rhythmicity (Lundkvist et al., 2005). It has been proposed that an increase in $\left[\mathrm{Ca}^{2+}\right]_{\mathrm{i}}$ activates a signaling pathway that ultimately shifts the phase of the circadian clock (Ding et al., 1994, 1997, 1998). Although glutamate, NMDA, or AMPA application will increase intracellular $\mathrm{Ca}^{2+}$ in SCN neurons, the physiological $\mathrm{Ca}^{2+}$ sig- 

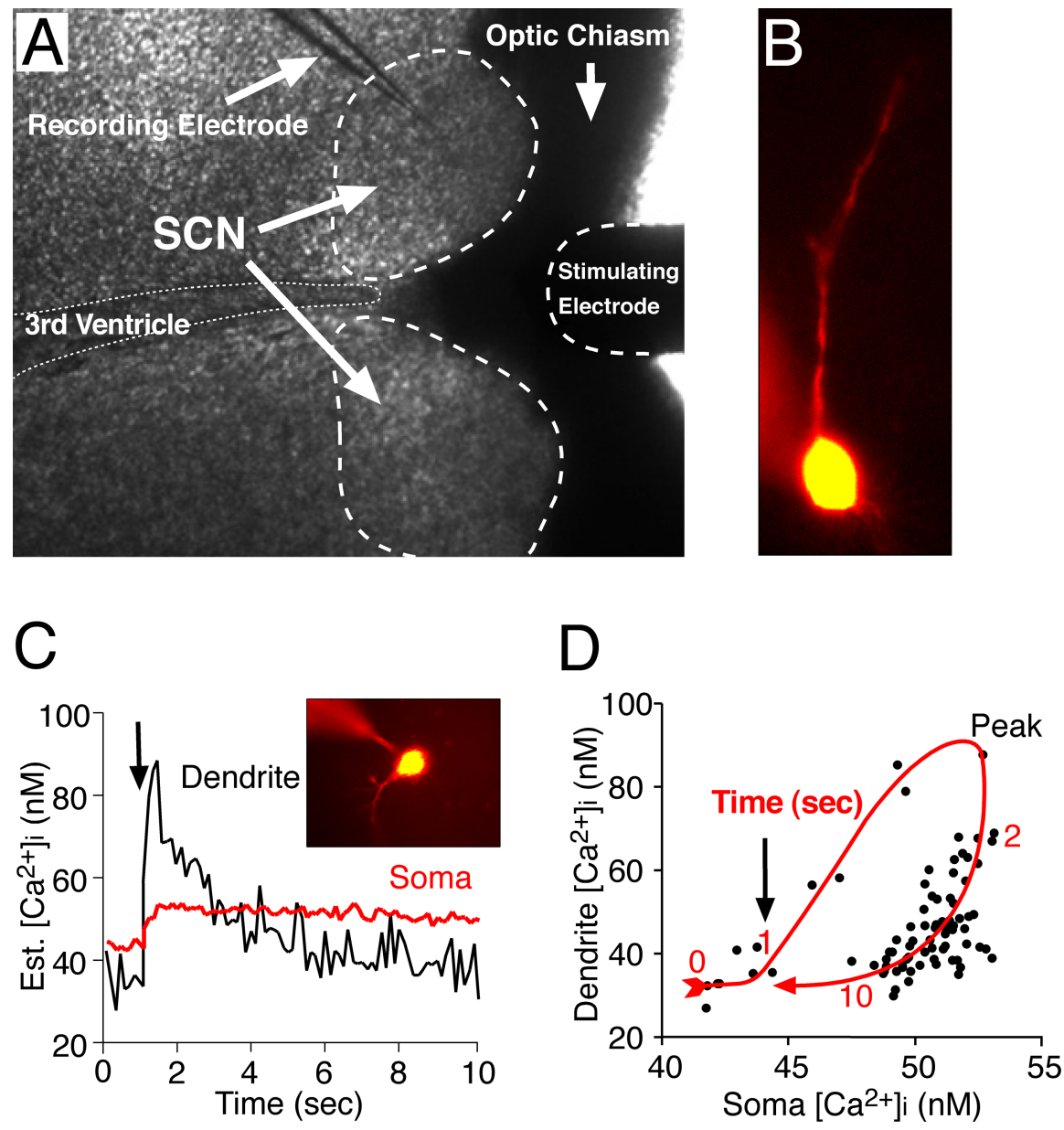

Figure 1. Simultaneous recording of membrane potential and $\left[\mathrm{Ca}^{2+}\right]_{\mathrm{i}}$ in SCN neurons. $A$, Example of the recording setup showing a coronal hypothalamic slice and the placement of stimulating and recording microelectrodes. A bipolar electrode positioned in the optic chiasm was used to stimulate the RHT. $B$, An SCN neuron recorded with a microelectrode filled with an internal solution containing the $\left[\mathrm{Ca}^{2+}\right]_{i}$-sensitive probe fura-2, which diffuses into the soma and dendritic arbor. $\boldsymbol{C}$, Estimated (Est.) $\left[\mathrm{Ca}^{2+}\right]_{\mathrm{i}}$ changes evoked in the soma and dendrites of a voltage-clamped SCN neuron (inset) by $10 \mathrm{stimuli}(10 \mathrm{~Hz}$; arrow) applied to the optic chiasm. $\boldsymbol{D}$, Dendritic $\left[\mathrm{Ca}^{2+}\right]$ i response was both larger in amplitude and faster to decay than in the soma, showing a clockwise hysteresis-loop temporal relationship.

naling produced by glutamate released from RHT synapses has not been described previously. We therefore performed experiments to examine the changes in $\left[\mathrm{Ca}^{2+}\right]_{\mathrm{i}}$ of SCN neurons after RHT stimulation.

\section{Materials and Methods}

Slice preparation. Male Sprague Dawley rats were housed for at least 1 week on a $12 \mathrm{~h}$ light/dark schedule. During the light phase, 4- to 6-weekold rats were anesthetized with halothane, their brains were removed, and coronal hypothalamic slices $(220-250 \mu \mathrm{m}$ thick) containing the SCN were cut with a vibrating blade microtome (VT1000S; Leica, Nussloch, Germany), while the tissue was surrounded by ice-cold artificial CSF (ACSF) containing the following (in $\mathrm{mm}$ ): $120 \mathrm{NaCl}, 2.5 \mathrm{KCl}, 1.2$ $\mathrm{NaH}_{2} \mathrm{PO}_{4}, 5 \mathrm{MgCl}_{2}, 0.5 \mathrm{CaCl}_{2}, 10$ glucose, and $26 \mathrm{NaHCO}_{3}$, adjusted to 300 mOsm with sucrose and saturated with $5 \% \mathrm{CO}_{2}$ and $95 \% \mathrm{O}_{2}$. The slices were maintained in a recording chamber $\left(25-30^{\circ} \mathrm{C}\right)$ with a continuous laminar flow $(2 \mathrm{ml} / \mathrm{min})$ of an ACSF solution consisting of the following (in mM): $120 \mathrm{NaCl}, 2.5 \mathrm{KCl}, 1.2 \mathrm{NaH}_{2} \mathrm{PO}_{4}, 1.2 \mathrm{MgCl}_{2}, 2.4$ $\mathrm{CaCl}_{2}, 10$ glucose, 10 HEPES, and $26 \mathrm{NaHCO}_{3}$, adjusted to $300 \mathrm{mOsm}$ with sucrose and bubbled with $5 \% \mathrm{CO}_{2}$ and $95 \% \mathrm{O}_{2}$. Picrotoxin $(50 \mu \mathrm{M})$ was added to prevent activation of $\mathrm{GABA}_{\mathrm{A}}$ receptors by evoked transmitter release from $S C N$ GABAergic neurons. The Institutional Animal Care and Use Committee of Oregon Health \& Science University approved, in advance, all procedures involving animals.
Patch-clamp recording. Whole-cell patchclamp recordings in SCN neurons were performed $0.5-8 \mathrm{~h}$ after slice preparation. Neurons were selected from the ventral SCN, because these cells have a higher probability of having RHT synapses. A few cells that did not respond to RHT stimulation were used to study the effects of membrane depolarization on $\left[\mathrm{Ca}^{2+}\right]_{\mathrm{i}}$. Whole-cell patch electrodes had an outside tip diameter of $\sim 1 \mu \mathrm{m}$ and resistances of $7-10 \mathrm{M} \Omega$ when filled with a solution containing the following (in $\mathrm{mm}$ ): $140 \mathrm{~K}$-gluconate, $5 \mathrm{KCl}, 10$ HEPES, 4 ATP, and 0.4 GTP, adjusted to $\mathrm{pH} 7.3$ with $\mathrm{KOH}$ at 290-300 mOsm. In some experiments, $\mathrm{KCl}$ was substituted for the $\mathrm{K}$-gluconate. After microelectrode contact with an SCN neuron, negative pressure was applied to form seals with resistances of $1-5 \mathrm{G} \Omega$. Additional negative pressure was used to rupture the cell membrane to whole-cell mode. Currents were measured under voltage clamp at a holding potential of $-60 \mathrm{mV}$. Membrane voltage was measured in current-clamp mode with an Axoclamp 2A amplifier (Molecular Devices, Union City, CA) or a HEKA Elektronik (Lambrecht, Germany) EPC9 amplifier and recorded using the data acquisition program Pulse (HEKA Elektronik) and analyzed using Igor (version 5; Wavemetrics, Lake Oswego, OR).

Measurement of intracellular $\mathrm{Ca}^{2+}$. Two methods were used to load SCN neurons with $\mathrm{Ca}^{2+}$-sensitive probes. In the first, microelectrodes were filled with the internal solution to which fura-2 pentapotassium salt $(250 \mu \mathrm{M})$ or bis-fura-2 hexapotassium salt $(250 \mu \mathrm{M})$ was added (Invitrogen, Carlsbad, CA). After entering whole-cell mode, the SCN neuron including the dendrites rapidly filled with fluorescent probe (Fig. $1 B$ ) and quickly reached a steadystate $\mathrm{Ca}^{2+}$ concentration. A slow upward drift in $\left[\mathrm{Ca}^{2+}\right]_{i}$ was noted in longer-duration experiments. The second method was used to simultaneously record $\mathrm{Ca}^{2+}$ responses from multiple neurons. SCN neurons were loaded by treating the slice with fura-2 AM (2.5 mM) in DMSO for 1-2 min, followed by incubation with fura- $\mathrm{AM}(10 \mu \mathrm{M})$ in ACSF for $1 \mathrm{~h}$ (Yuste, 2000). To reduce the background signal and allow for deesterification, the slice was washed for $1-2 \mathrm{~h}$ before recording.

Quantitative $\mathrm{Ca}^{2+}$ measurements were obtained by recording a pair of images at an emission of $510 \pm 40 \mathrm{~nm}$ after excitation at 340 and $380 \mathrm{~nm}$. Excitation light was supplied via a monochronometer (Polychrome IV; T.I.L.L. Photonics, Martinsried, Germany) with a $10 \mathrm{~nm}$ bandwidth and passed through a UG11 optical filter to restrict harmonic wavelengths above $400 \mathrm{~nm}$. Optical recordings were made with a cooled CCD (ORCA-ER 12-bit level; Hamamatsu, Hamamatsu City, Japan) camera with acquisition time and binning adjusted to minimize photobleaching and maximize recording speed. Experiments were controlled via the digital imaging software Metafluor (Molecular Devices, Sunnyvale, CA). Optical data were converted to relative fluorescence intensity units, the background was subtracted, and the intracellular $\mathrm{Ca}^{2+}\left(\left[\mathrm{Ca}^{2+}\right]_{\mathrm{i}}\right)$ was estimated using the following formula: $\left[\mathrm{Ca}^{2+}\right]_{\mathrm{i}}=\left(R-R_{\min }\right) /\left(R_{\max }-\right.$ $R) \times\left(f_{\min } / f_{\max }\right) \times K_{\mathrm{d}}$, where $R$ is the emission ratio after excitation at 340 and $380 \mathrm{~nm}$, ratio maximums $\left(R_{\max }\right)$ and minimums $\left(R_{\min }\right)$ for each probe were determined in vitro using $\mathrm{CaCl}_{2}(10 \mathrm{~mm})$ or EGTA $(10 \mathrm{~mm})$, $f_{\min }$ and $f_{\max }$ are the fluorescence intensities at $380 \mathrm{~nm}$ under $\mathrm{Ca}^{2+}$-free and $\mathrm{Ca}^{2+}$-saturating conditions, and $K_{\mathrm{d}}$ is the $\mathrm{Ca}^{2+}$ disassociation constant of the indicator, taken to be $370 \mathrm{~nm}$ for bis fura-2 (Invitrogen) and $224 \mathrm{~nm}$ for fura-2 (Grynkiewicz et al., 1985). Stimulation pulses (200 $\mu \mathrm{s})$ 
were applied at the indicated frequencies via a concentric bipolar electrode placed in the optic chiasm $\sim 200 \mu \mathrm{m}$ from the SCN (Fig. $1 A$ ).

\section{Results}

The magnitude of postsynaptic $\left[\mathrm{Ca}^{2+}\right]_{i}$ transients was dependent on RHT stimulation frequency and duration An increase in $\left[\mathrm{Ca}^{2+}\right]_{\mathrm{i}}$ within SCN neurons is believed to be required to initiate the transduction events leading to entrainment of SCN neurons to the day/night cycle (Ding et al., 1994, 1997, 1998). The first set of experiments was designed to test the hypothesis that the magnitude of postsynaptic changes in somatic $\left[\mathrm{Ca}^{2+}\right]_{\mathrm{i}}$ was dependent on the RHT stimulus frequency. To examine the relationship between membrane potential and $\left[\mathrm{Ca}^{2+}\right]_{\mathrm{i}}$ in SCN neurons, we prepared coronal slices and used whole-cell patch-clamp recordings with microelectrodes containing a $\mathrm{Ca}^{2+}$ free internal solution with the $\mathrm{Ca}^{2+}$ sensitive probe fura-2 or bis-fura-2 (Fig. $1 A)$. Probe-filled dendritic processes within the focal plane were visible in $42 \%$ of recorded neurons (Fig. $1 B$ ). Electrical stimulation of the RHT (200 $\mu$ s pulses) evoked an increase in both somatic and dendritic $\left[\mathrm{Ca}^{2+}\right]_{\mathrm{i}}$ (Fig. 1C). The evoked dendritic $\left[\mathrm{Ca}^{2+}\right]_{\mathrm{i}}$ responses were both larger in amplitude and faster to decay than in the soma, demonstrating a clockwise hysteresis-loop temporal relationship (Fig. 1D).

SCN neurons were hyperpolarized up to $\sim 10 \mathrm{mV}$ to slow $(0-3 \mathrm{~Hz})$ or eliminate spontaneous action potential firing to more easily observe RHT-evoked $\left[\mathrm{Ca}^{2+}\right]_{\mathrm{i}}$ changes. The optic chiasm was then stimulated at frequencies from 0.2 to $20 \mathrm{~Hz}$, which is within the physiological range of light-sensitive retinal ganglion cell action potential firing (Berson et al., 2002; Warren et al., 2003; Tu et al., 2005) (Fig. 2). At stimulus frequencies $<1 \mathrm{~Hz}$, individual stimuli evoked a small elevation of $\left[\mathrm{Ca}^{2+}\right]_{i}$ in the soma that decayed to near baseline before the next stimulus occurred (Fig. 2). Dendritic $\mathrm{Ca}^{2+}$ responses to RHT stimulation were larger and faster to decay than in the soma (Fig. 2B). Stimulation frequencies of $\geq 1 \mathrm{~Hz}$ resulted in larger accumulated elevations of $\left[\mathrm{Ca}^{2+}\right]_{i}$ in the soma that were dependent on the stimulus rate. The frequency dependence of $\left[\mathrm{Ca}^{2+}\right]_{\mathrm{i}}$ response in the soma was similar in neurons recorded during the day and those recorded during the night (Fig. 3). The relationship between RHT stimulation frequency and the $\mathrm{Ca}^{2+}$ response in the soma was described by a hyperbolic function $\left[\Delta \mathrm{Ca}^{2+}=E_{\max }\right.$ $\times$ frequency/($\left(\mathrm{EF}_{50}+\right.$ frequency) $]$, where $E_{\max }$ is the maximal $\mathrm{Ca}^{2+}$ response and $\mathrm{EF}_{50}$ is the stimulus frequency at half the maximal response. The increased $\left[\mathrm{Ca}^{2+}\right]_{\mathrm{i}}$ in the soma reached a plateau at $\sim 10 \mathrm{~Hz}$ and was similar during both the day $\left(E_{\max }=\right.$
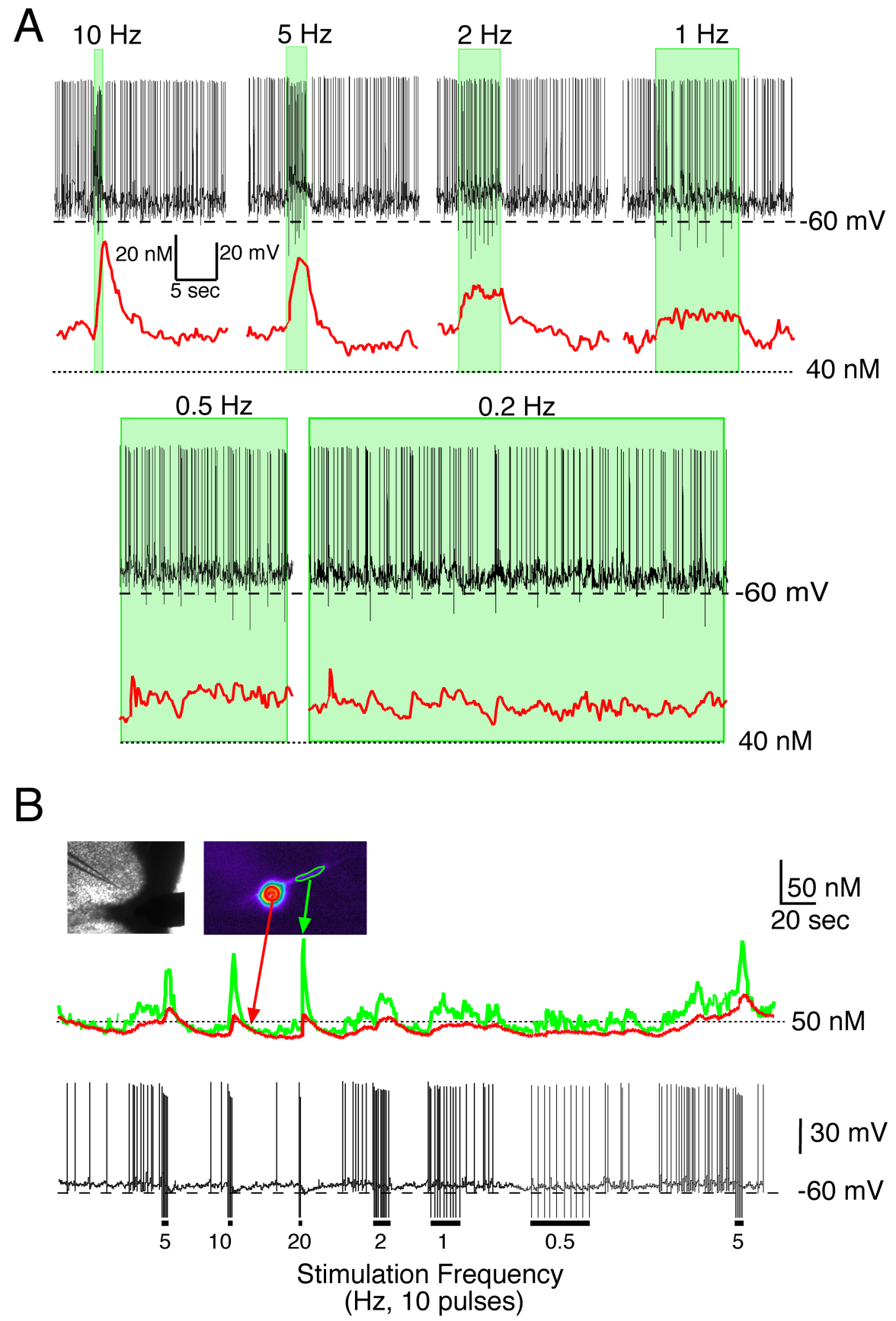

Figure 2. The magnitude of postsynaptic $\left[\mathrm{Ca}^{2+}\right]_{i}$ transients in SCN neurons were dependent on the RHT stimulation frequency. $\boldsymbol{A}$, The RHT wasstimulated with 10 pulses (200 $\mu$ s each) at the indicated frequencies while recording $\mathrm{Ca}^{2+}$ responses (red line) in the soma in a current-clamped SCN neuron spontaneously firing at $\sim 3 \mathrm{~Hz}$ during the day. Shaded areas represent the duration of the stimulation train. Accumulation of somatic $\mathrm{Ca}^{2+}$ was not observed during low-frequency optic chiasm stimulation. $B, C^{2+}$ response in the soma and dendrites after RHT stimulation of a slowly firing SCN neuron during the night. Ten pulses were applied at the frequencies indicated. The $\mathrm{Ca}^{2+}$ response to 10 and $20 \mathrm{~Hz}$ RHT stimulation were similar.

$\left.30 \pm 0.8 \mathrm{nM} ; \mathrm{EF}_{50}=1.2 \pm 0.1 \mathrm{~Hz} ; n=6\right)$ and night $\left(E_{\max } 34 \pm 1.2\right.$ $\left.\mathrm{nM} ; \mathrm{EF}_{50}=1.5 \pm 0.2 \mathrm{~Hz} ; n=3\right)$.

Retinal ganglion cells fire action potentials for the entire duration of the light exposure (Berson et al., 2002; Warren et al., 2003; Tu et al., 2005). The results presented above were obtained using 10 stimulations of the RHT at different frequencies resulting in pulse trains of different durations (e.g., $1 \mathrm{~s}$ for $10 \mathrm{~Hz}$ vs $0.5 \mathrm{~s}$ for $20 \mathrm{~Hz}$ ). However, the number and duration of evoked action potentials may carry important environmental light information to the SCN. Therefore, we evaluated the effects of the number 


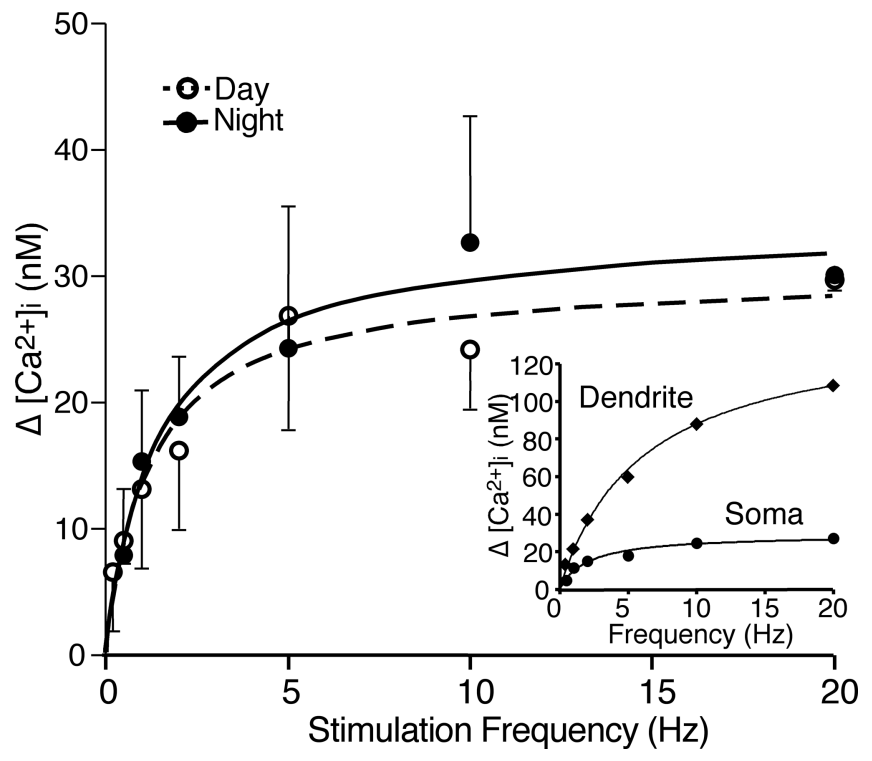

Figure 3. The relationship between RHT stimulation frequency and the $\mathrm{Ca}^{2+}$ response. Ten stimulus pulses were applied to the RHT at the frequencies indicated. Each data point represents the mean \pm SEM of the increase in $\left[\mathrm{Ca}^{2+}\right]_{i}$ in the soma recorded during the day $\left(E_{\max }=30 \mathrm{~nm}\right.$; $\left.\mathrm{EF}_{50}=1.2 \mathrm{~Hz} ; n=2-6\right)$ and night $\left(E_{\max }=34 \mathrm{~nm} \mathrm{EF}_{50}=1.5 \mathrm{~Hz} ; n=2-3\right)$. Day and night $\left[\mathrm{Ca}^{2+}\right]_{\mathrm{i}}$ responses were not statistically different. The inset shows an example of a $\mathrm{Ca}^{2+}$ response from a single SCN neuron in the soma and dendrite receiving RHT stimulation at different frequencies.

of stimuli-induced SCN action potentials on changing $\left[\mathrm{Ca}^{2+}\right]_{i}$ at various RHT stimulation frequencies. At either 0.5 or $1 \mathrm{~Hz}$ stimulation in both the soma and dendrites, $\left[\mathrm{Ca}^{2+}\right]_{\mathrm{i}}$ quickly reached a low-amplitude plateau after a few stimuli (Fig. $4 A, B)$. However, stimulation at frequencies faster than $1 \mathrm{~Hz}$ resulted in larger $\left[\mathrm{Ca}^{2+}\right]_{\mathrm{i}}$ changes that did not plateau within 10 stimuli. Increasing the pulse train to 50 stimuli produced similar changes of $\left[\mathrm{Ca}^{2+}\right]_{i}$ in the soma, which reached a plateau during low-frequency $(1 \mathrm{~Hz})$ stimulation. A hyperbolic rise in $\left[\mathrm{Ca}^{2+}\right]_{\mathrm{i}}$ was observed during $2-5 \mathrm{~Hz}$ stimulation, and a linear rise in somatic $\left[\mathrm{Ca}^{2+}\right]_{\mathrm{i}}$ was observed during $10-20 \mathrm{~Hz}$ stimulus trains (Fig. 4C).

Because RHT stimulation (presynaptic) may or may not evoke a corresponding postsynaptic action potential in a given SCN neuron, we evaluated the relationship between the $\left[\mathrm{Ca}^{2+}\right]_{\mathrm{i}}$ response and the number of action potentials evoked by 10 optic chiasm stimuli at $10 \mathrm{~Hz}$. The change in $\left[\mathrm{Ca}^{2+}\right]_{\mathrm{i}}$ was linearly dependent on the number of postsynaptic action potentials (Fig. $4 D)$ with a slope of $2.5 \pm 0.5 \mathrm{nM}$ per action potential $\left(r^{2}=0.77\right.$; $n=6)$ in soma during the day and $2.3 \pm 0.4 \mathrm{~nm}$ per action potential $\left(r^{2}=0.92 ; n=8\right)$ during the night. Day and night $\left[\mathrm{Ca}^{2+}\right]_{\mathrm{i}}$ responses were not statistically different $(p>0.75$, leastsquares). These data suggest that activation of the RHT produces a frequency-dependent increase in the action potential firing of SCN neurons that is concomitantly associated with an increase in $\left[\mathrm{Ca}^{2+}\right]_{\mathrm{i}}$. Two mechanisms may contribute to the rapid increase in $\left[\mathrm{Ca}^{2+}\right]_{\mathrm{i}}$. The first is activation of postsynaptic AMPA and NMDA receptors and an increased flow of $\mathrm{Ca}^{2+}$ through the associated ion channels. The second mechanism is $\mathrm{Ca}^{2+}$ flowing through voltage-gated $\mathrm{Ca}^{2+}$ channels, opened by the membrane depolarization and subsequent action potential firing of the SCN neuron.
Somatic and dendritic $\left[\mathrm{Ca}^{2+}\right]_{\mathrm{i}}$ transients evoked by action potentials and EPSPs

To evaluate the mechanism of RHT-evoked increase in $\mathrm{Ca}^{2+}$ in SCN neurons, we stimulated the optic chiasm and evoked EPSPs and action potentials. No detectable increase in $\left[\mathrm{Ca}^{2+}\right]_{i}$ within the soma (Fig. $5 A$ ) or dendrites (data not shown) was associated with individual EPSPs, which could be blocked by addition of the AMPA and NMDA receptor antagonists (Fig. 5D, inset). However, when RHT stimulation evoked EPSPs that triggered action potentials, the $\left[\mathrm{Ca}^{2+}\right]_{\mathrm{i}}$ increased in a stepwise manner (Fig. $5 B, C)$. We examined whether trains of EPSPs would increase $\left[\mathrm{Ca}^{2+}\right]_{\mathrm{i}}$ levels in the soma. SCN neurons were hyperpolarized just below action potential threshold, and 10 RHT stimuli were applied at $10 \mathrm{~Hz}$. The RHT-evoked EPSPs did not significantly change $\left[\mathrm{Ca}^{2+}\right]_{\mathrm{i}}\left(\Delta \mathrm{Ca}^{2+}=0.05 \pm 0.20 \mathrm{nM} ; p=0.35\right.$, paired $t$ test; $n=12$ neurons; mean EPSPs amplitude, $\sim 6.2 \pm 0.7 \mathrm{mV})$.

Experiments were performed to insure that we could measure $\left[\mathrm{Ca}^{2+}\right]_{\mathrm{i}}$ changes induced by glutamate receptor activation under our experimental conditions. $\left[\mathrm{Ca}^{2+}\right]_{i}$ was measured in the soma of SCN neurons while activating AMPA and NMDA receptors with exogenous ligands. Adult coronal brain slices containing SCN neurons were loaded with fura-2 AM and allowed to undergo deesterification for several hours before briefly applying glutamate (Fig. 6A, B) or NMDA (Fig. 6C,D). Both glutamate and NMDA induced in a concentration-dependent manner $\left[\mathrm{Ca}^{2+}\right]_{\mathrm{i}}$ transients that were readily blocked by glutamate receptor antagonists (Fig. 6B). Unlike synaptically released glutamate, exogenous glutamate simultaneously activates all functional glutamate receptors associated with that neuron for time durations orders of magnitude longer than would occur during synaptic transmission.

We examined the $\left[\mathrm{Ca}^{2+}\right]_{\mathrm{i}}$ response during a sequence of 10 current pulses in the presence of TTX to simulate the brief membrane depolarizations that occur during EPSPs and action potentials. Evoked changes in $\left[\mathrm{Ca}^{2+}\right]_{\mathrm{i}}$ varied exponentially with voltage between -60 and $-10 \mathrm{mV}$ (Fig. $6 E, F$ ). Small changes in voltage-approximating evoked EPSPs $(5-10 \mathrm{mV})$ produced little measurable change in somatic $\left[\mathrm{Ca}^{2+}\right]_{\mathrm{i}}$. These data suggest that glutamate release at RHT-SCN synapses induces EPSPs in the SCN, but without an associated action potential, little or no change in somatic $\left[\mathrm{Ca}^{2+}\right]_{\mathrm{i}}$ occurs. Therefore, under normal physiological conditions, it is likely that RHT signaling must involve evoked action potentials in SCN neurons for $\mathrm{Ca}^{2+}$ to act as a second messenger to induce phase changes of the circadian clock.

\section{Postsynaptic $\mathrm{Ca}^{2+}$ transients evoked by membrane depolarization and RHT stimulation are attenuated by blocking L-type $\mathrm{Ca}^{2+}$ channels}

The next sets of experiments were designed to further examine the role that membrane potential depolarization plays in the increase in $\left[\mathrm{Ca}^{2+}\right]_{\mathrm{i}}$ that follows RHT stimulation. In voltageclamped SCN neurons, the holding potential $(-60 \mathrm{mV})$ was briefly $(200 \mathrm{~ms})$ stepped in $20 \mathrm{mV}$ increments to $+20 \mathrm{mV}$ evoking corresponding transients of $\left[\mathrm{Ca}^{2+}\right]_{\mathrm{i}}$ (Fig. $7 A$ ). For a given voltage step, the dendritic $\left[\mathrm{Ca}^{2+}\right]_{\mathrm{i}}$ responses were larger in amplitude and decayed faster than the somatic $\left[\mathrm{Ca}^{2+}\right]_{\mathrm{i}}$ changes (Fig. $7 B)$. The difference in somatic and dendritic $\left[\mathrm{Ca}^{2+}\right]_{\mathrm{i}}$ changes are similar to those observed after stimulation of the optic chiasm (see also Fig. 1C). With repetitive voltage steps, the somatic $\left[\mathrm{Ca}^{2+}\right]_{\mathrm{i}}$ increased, and the ratio of dendritic to somatic response decreased (Fig. 7C).

The $\left[\mathrm{Ca}^{2+}\right]_{\mathrm{i}}$ was larger at more depolarized membrane poten- 
tials with a maximum $\left[\mathrm{Ca}^{2+}\right]_{\mathrm{i}}$ in the dendrites and soma occurring between 0 and $+40 \mathrm{mV}$. Nimodipine reduced the amplitude of the $\left[\mathrm{Ca}^{2+}\right]_{\mathrm{i}}$ transients over the entire voltage range in both the soma and dendrites (Fig. $8 A$ ). In the presence of $\operatorname{TTX}(0.5 \mu \mathrm{M})$, nimodipine $(20 \mu \mathrm{M})$ significantly reduced the somatic $\left[\mathrm{Ca}^{2+}\right]_{i}$ transients to $39.7 \pm 3.9 \%$ ( $n=5$ neurons; $p \leq$ 0.01 ) of control during the day, which was not statistically different $(p=0.39)$ from the reduction to $43.6 \pm 6.1 \%(n=4, p \leq$ 0.01 ) during the night. The peak voltages generated by these current pulses were not significantly different $(p=0.91)$ during the day $(-24.0 \pm 1.4 \mathrm{mV})$ and night $(-24.2 \pm 1.5 \mathrm{mV})$. The decay of the peak $\left[\mathrm{Ca}^{2+}\right]_{\mathrm{i}}$ transient evoked was slower in the soma than in the dendrites. First-order elimination of $\left[\mathrm{Ca}^{2+}\right]_{\mathrm{i}}$ in the soma had $\tau=7.7 \pm 2.3 \mathrm{~s}(n=9)$ compared with $0.70 \pm 0.15 s(n=8 ; p \leq 0.009)$ in dendrites. No significant differences were observed with $\mathrm{Ca}^{2+}$ elimination between day (soma: $7.4 \pm 2.2 \mathrm{~s}, n=5$; dendrite: $0.71 \pm 0.14 \mathrm{~s}$, $n=4$ ) versus night (soma: $8.7 \pm 3.5 \mathrm{~s}, n=4$, $p>0.76$; dendrite: $0.87 \pm 0.28 \mathrm{~s}, n=4, p>$ 0.56 ) or control (soma: $7.7 \pm 2.3 \mathrm{~s}, n=9$; dendrite: $0.70 \pm 0.15 \mathrm{~s}, n=8$ ) versus nimodipine (soma: $8.3 \pm 2.9 \mathrm{~s}, n=9, p>0.88$; dendrite: $0.87 \pm 0.16 \mathrm{~s}, n=8, p>0.34$ ).

To evaluate whether nimodipine would similarly reduce RHT-induced $\mathrm{Ca}^{2+}$ transients, the RHT was stimulated during the day at various frequencies before and after nimodipine treatment. Nimodipine significantly attenuated RHTevoked $\mathrm{Ca}^{2+}$ transients over a range of stimulation frequencies with a mean reduction in $39 \%$ at $20 \mathrm{~Hz}, 32 \%$ at $10 \mathrm{~Hz}$, $33 \%$ at $1 \mathrm{~Hz}$, and $21 \%$ at $0.5 \mathrm{~Hz}$ (Fig. $8 B$ ). These observations suggest that L-type voltage-dependent $\mathrm{Ca}^{2+}$ channels mediate a significant proportion of depolarizationinduced $\mathrm{Ca}^{2+}$ transients in SCN neurons.

\section{Spontaneous action potential firing and} $\left[\mathrm{Ca}^{2+}\right]_{\mathrm{i}}$ in the soma and dendritic processes SCN neuronal conductance, firing frequency, and $\left[\mathrm{Ca}^{2+}\right]_{i}$ vary between the subjective day and night. The next experiments were designed to evaluate the effect of individual action potentials and action potential frequency on $\left[\mathrm{Ca}^{2+}\right]_{\mathrm{i}}$. SCN neurons demonstrated a temporal relationship between the spontaneous action potential frequency and somatic $\left[\mathrm{Ca}^{2+}\right]_{\mathrm{i}}$ (Fig. 9A). The somatic and dendritic $\left[\mathrm{Ca}^{2+}\right]_{\mathrm{i}}$ tracked with changes of the membrane potential and action potential firing frequency (Fig. 9B,C). At slow frequencies, the increase in somatic $\left[\mathrm{Ca}^{2+}\right]_{\mathrm{i}}$ after each action potential was additive, such
A
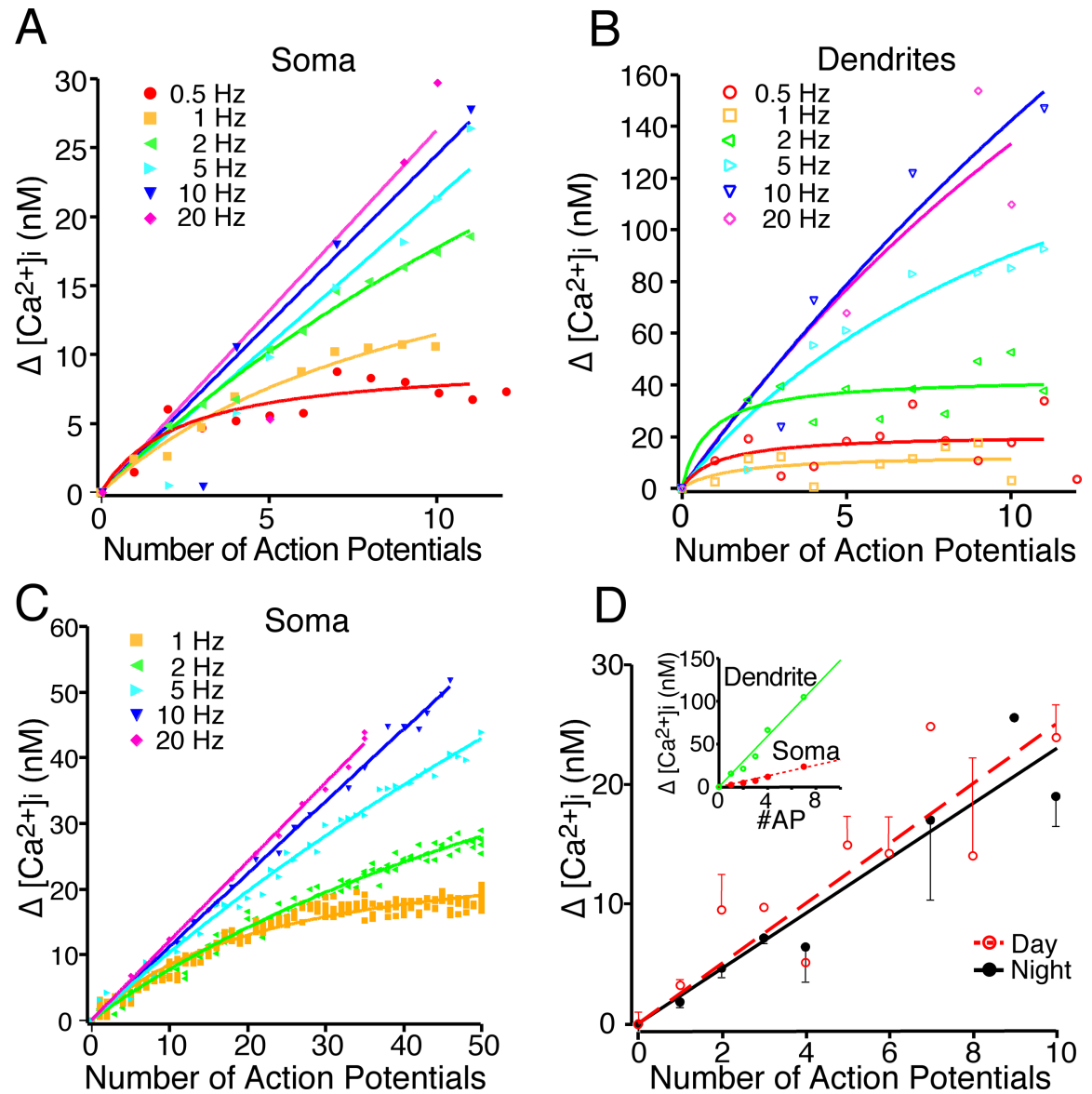

Figure 4. The change in $\left[\mathrm{Ca}^{2+}\right]_{\mathrm{i}}$ with sequential action potentials was dependent on the number and frequency of stimuli. $\boldsymbol{A}$, $\boldsymbol{B}$, The optic chiasm was stimulated $(0.5-20 \mathrm{~Hz})$, and the number of action potentials and the $\left[\mathrm{Ca}^{2+}\right]_{i}$ were recorded. The number of action potentials recorded during a 10 stimuli train was plotted versus the change in $\left[\mathrm{Ca}^{2+}\right]_{\mathrm{i}}$ in the soma and dendrite of an SCN neuron recorded during the night. Note that at low stimulation frequencies, a few spontaneous action potentials contributed to the change $(\Delta)$ in $\left[\mathrm{Ca}^{2+}\right]_{\mathrm{i}}$. The $\Delta\left[\mathrm{Ca}^{2+}\right]_{\mathrm{i}}$ reached a plateau during low-frequency stimulation, whereas higher frequencies of the $\Delta\left[\mathrm{Ca}^{2+}\right]_{i}$ had a linear response. $C$, Example of the number of action potentials versus $\left[\mathrm{Ca}^{2+}\right]_{i}$ change recorded during the night after 50 stimuli. Note that at $20 \mathrm{~Hz}$, not all stimuli resulted in an evoked action potential. $\boldsymbol{D}$, The $\left[\mathrm{Ca}^{2+}\right]_{\mathrm{i}}$ response was dependent on the number of postsynaptic action potentials evoked by optic chiasm stimulation. The optic chiasm was stimulated 10 times at $10 \mathrm{~Hz}$, which evoked a variable number of postsynaptic action potentials (AP). Each point represents the mean \pm SEM recorded from the soma of SCN neurons recorded during the day (slope, $2.5 \mathrm{~nm}$ per action potential; $n=6$ ) and night (slope, $2.3 \mathrm{~nm}$ per action potential; $n=8$ ). Day and night $\left[\mathrm{Ca}^{2+}\right]_{\mathrm{i}}$ responses were not statistically different. The inset shows an example of the postsynaptic $\left[\mathrm{Ca}^{2+}\right]_{i}$ response in the soma and dendrite of a single neuron that fired a variable number of postsynaptic action potentials during a train of optic chiasm stimulations.

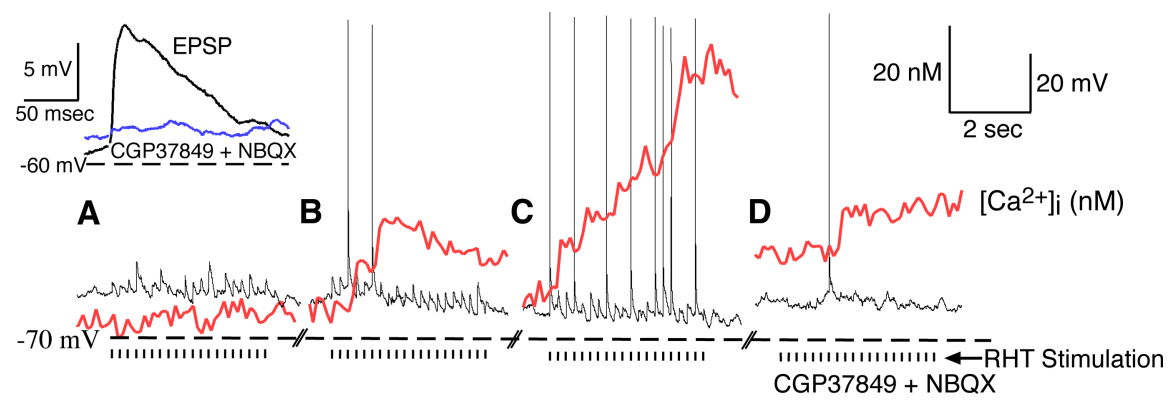

Figure 5. A rise in $\left[\mathrm{Ca}^{2+}\right]_{i}$ was not associated with evoked EPSPs in the absence of action potential firing. $\boldsymbol{A}-\boldsymbol{C}$, RHT stimulation (tic marks, stimulation artifact removed) evoked EPSPs (black) but had little or no effect on estimated $\left[\mathrm{Ca}^{2+}\right]_{\mathrm{i}}$ (red) within the soma $(\boldsymbol{A})$, whereas EPSPs that triggered action potentials increased $\left[\mathrm{Ca}^{2+}\right]_{i}$ in a stepwise manner $(\boldsymbol{B}, \boldsymbol{C})$. D, Treatment with the AMPA antagonist NBQX (2,3-dioxo-6-nitro-1,2,3,4-tetrahydrobenzoquinoxaline-7-sulfonamide; $10 \mu \mathrm{M}$ ) and the NMDA antagonist CGP 37849 [(E)-( \pm )-2-amino-4-methyl-5-phosphono-3-pentenoic acid; $20 \mu \mathrm{m}$ ] inhibited the EPSPs (inset) but did not alter the rise in $\left[\mathrm{Ca}^{2+}\right]_{\mathrm{i}}$ induced by a spontaneous action potential. 
A

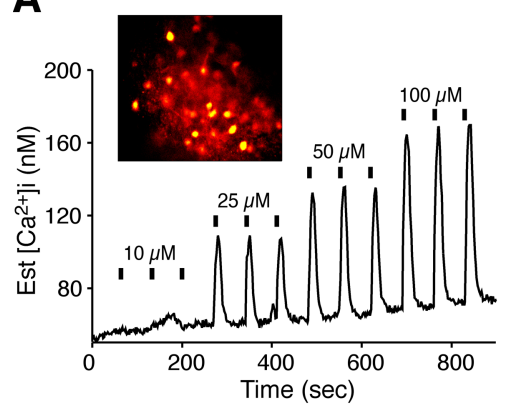

C

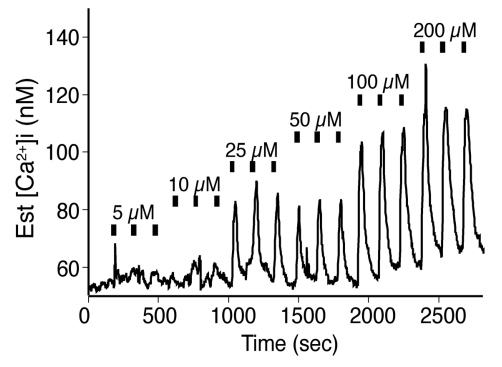

E

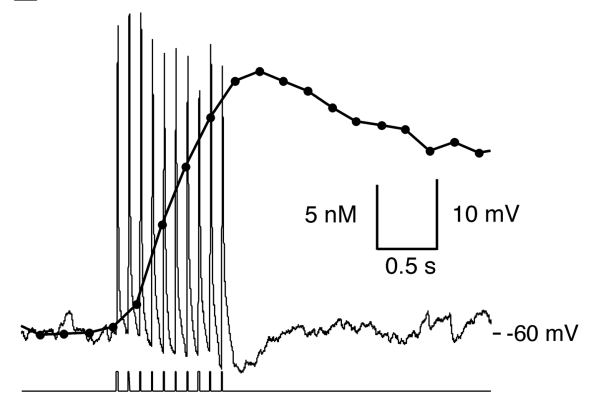

B

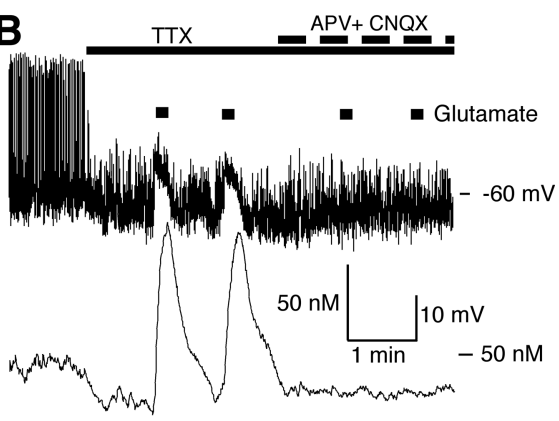

D

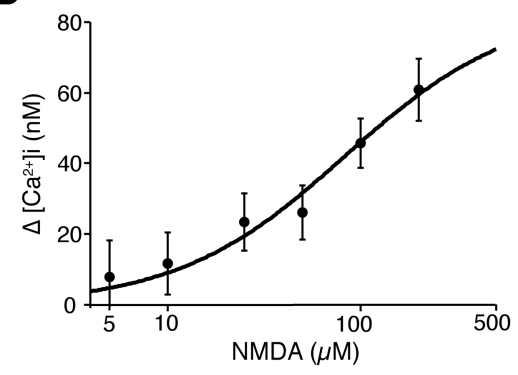

$\mathbf{F}$

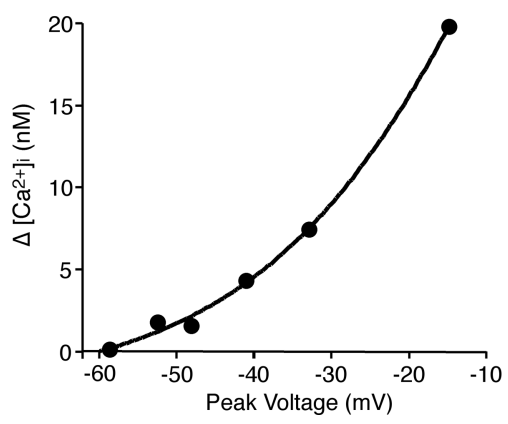

Figure 6. Glutamate evoked $\left[\mathrm{Ca}^{2+}\right]_{\mathrm{i}}$ transients in adult SCN neurons. $\boldsymbol{A}$, The mean change in $\left[\mathrm{Ca}^{2+}\right]_{\mathrm{i}}$ in 27 simultaneously recorded SCN neurons induced by glutamate. Bars indicate a 10 s glutamate treatment. The inset shows fura-2-loaded SCN cells. The concentration response relationship of this experiment had an $\mathrm{EC}_{50}$ of $31 \mu \mathrm{m}$ for glutamate. $\boldsymbol{B}$, Glutamate induced $\left[\mathrm{Ca}^{2+}\right]_{\mathrm{i}}$ transients and membrane depolarizations that were blocked by APV (50 $\mu \mathrm{m})$ and CNQX (10 $\mu \mathrm{m})$ in a current-clamped SCN neuron during the day. $C$, The amplitude of NMDA-evoked $\left[\mathrm{Ca}^{2+}\right]_{\mathrm{i}}$ transients was dependent on the NMDA concentration. Bars indicate a 15 s exposure to NMDA. D, Concentration-response curve for NMDA-induced $\Delta\left[\mathrm{Ca}^{2+}\right]_{\mathrm{i}}$, in which each point represents the mean \pm SEM of 5-10 cells from four different experiments. The $\mathrm{EC}_{50}$ value for NMDA was estimated to be $83 \mu \mathrm{M}$. $\boldsymbol{E}$, Example showing the change in $\left[\mathrm{Ca}^{2+}\right]_{\mathrm{i}}$ in response to membrane depolarization in a current-clamped SCN neuron. The neuron was depolarized with 10 pulses $(100 \mathrm{pA}, 10 \mathrm{~ms})$ in the presence of picrotoxin $(50 \mu \mathrm{m})$ and $\mathrm{TTX}(0.5 \mu \mathrm{m})$. The corresponding rise and fall of somatic $\left[\mathrm{Ca}^{2+}\right]_{\mathrm{i}}$ was similar to that evoked by action potentials. $\boldsymbol{F}$, The change in $\mathrm{Ca}^{2+}$ was plotted versus the peak membrane potential reached after current injection (10 pulses of 10,20,40,60, or $100 \mathrm{pA}$ at $10 \mathrm{~Hz}$ ) in the same neuron. Est., Estimated.

A

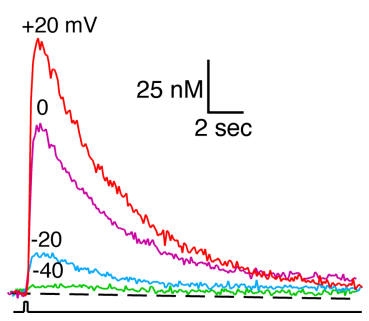

B

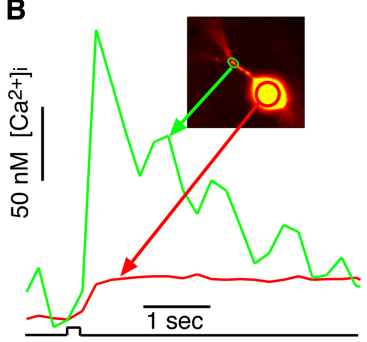

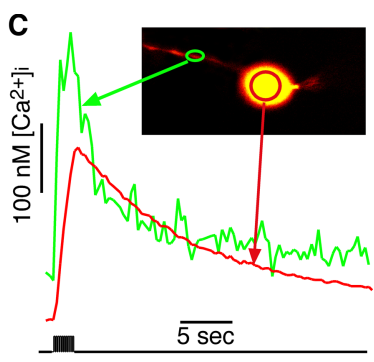

Figure 7. Membrane depolarization evokes postsynaptic $\mathrm{Ca}^{2+}$ transients in the soma and dendrites. $\boldsymbol{A}$, Membrane depolarization evoked $\mathrm{Ca}^{2+}$ transients in a voltage-clamped SCN neuron during the day. The holding potential $(-60 \mathrm{mV})$ was changed briefly $(200 \mathrm{~ms})$ to the indicated voltages. $\boldsymbol{B}$, Dendritic response was larger and faster than that observed in the soma. A currentclamped SCN neuron was given a brief depolarizing (200 ms, $100 \mathrm{pA})$ current pulse (step), with picrotoxin (50 $\mu \mathrm{m})$ and TTX (0.5 $\mu \mathrm{M})$, to block feedback from neighboring neurons. $C$, Repetitive depolarizations increase the ratio of the somatic to dendritic $\left[\mathrm{Ca}^{2+}\right]_{\mathrm{i}}$ response. A similar experiment as in $\boldsymbol{B}$ is shown, but the $\mathrm{SCN}$ neuron was voltage clamped at $-80 \mathrm{mV}$, and membrane was depolarized with $10(100 \mathrm{~ms})$ pulses to $+20 \mathrm{mV}(5 \mathrm{~Hz})$.

that a pair of action potentials increased $\left[\mathrm{Ca}^{2+}\right]_{\mathrm{i}}$ about twice that of a solitary action potential. If an action potential occurred before the $\mathrm{Ca}^{2+}$ transient decayed to baseline, then the $\left[\mathrm{Ca}^{2+}\right]_{\mathrm{i}}$ continued to increase. However, as seen with RHTevoked action potentials (Fig. 3), the $\left[\mathrm{Ca}^{2+}\right]_{\mathrm{i}}$ increased linearly at low frequencies and reached a plateau at faster action potential firing (Fig. 9A,B). Action potential-induced $\left[\mathrm{Ca}^{2+}\right]_{\mathrm{i}}$ changes were much larger in dendritic processes than in the soma and decayed more rapidly (Fig. 9C). Action potential peak voltages are brief (Jackson et al., 2004) but large enough to open voltage-dependent $\mathrm{Ca}^{2+}$ channels with a measurable influx of $\left[\mathrm{Ca}^{2+}\right]_{\mathrm{i}}$ in soma and dendrites. Prolonged spontaneous changes in membrane potential, without an associated action potential, evoked small changes in $\left[\mathrm{Ca}^{2+}\right]_{\mathrm{i}}$ (Fig. $9 C)$. The spontaneous action potential frequency of SCN neurons was $5.6 \pm 0.5 \mathrm{~Hz}$ (40 neurons) during the day and $1.6 \pm 0.2$ $\mathrm{Hz}$ at night (29 neurons; $p<0.0001)$. A single spontaneous action potential induced a rise in $\left[\mathrm{Ca}^{2+}\right]_{\mathrm{i}}$ of $2.9 \pm 0.5 \mathrm{nM}$ $(n=20)$ in the soma and $16.5 \pm 6.2 \mathrm{nM}$ $(n=8)$ in dendritic processes during the day. During the night, each action potential produced a $\left[\mathrm{Ca}^{2+}\right]_{\mathrm{i}}$ peak of $4.3 \pm 0.5$ $\mathrm{nM}(n=28)$ in the soma and $22.9 \pm 3.9 \mathrm{nM}$ $(n=13)$ in dendritic processes, which were not significantly different (soma, $p>$ 0.054; dendrite, $p>0.378$ ) from the day changes (Fig. 9D). $\left[\mathrm{Ca}^{2+}\right]_{\mathrm{i}}$ increased exponentially with increasing membrane potential between -80 and $-40 \mathrm{mV}$ (Fig. $9 E)$, regardless of the time of day.

RHT-evoked $\left[\mathrm{Ca}^{2+}\right]_{\mathrm{i}}$ transients are inversely correlated with spontaneous action potential frequency

The magnitude of RHT-evoked $\mathrm{Ca}^{2+}$ transients described above was not different between day and night conditions (Fig. 3 ). In these experiments, neurons were similarly hyperpolarized to lower the spontaneous action potential firing rate $(0-3 \mathrm{~Hz})$ to more easily observe RHTevoked $\mathrm{Ca}^{2+}$ responses. Because SCN action potential firing frequency is higher in neurons during the day than at night (Jobst and Allen, 2002; Pennartz et al., 2002; Ikeda, 2004; Pitts et al., 2006), it is conceivable that differences in spontaneous firing rate may modify RHT-evoked $\mathrm{Ca}^{2+}$ responses. The hyperbolic relationship of the change in $\mathrm{Ca}^{2+}$ with stimulation frequency (Fig. 3) implies that the incremental change in $\mathrm{Ca}^{2+}$ would decrease with increasing firing frequency, such that the $\left[\mathrm{Ca}^{2+}\right]_{\mathrm{i}}$ of a SCN neuron spontane- 
A

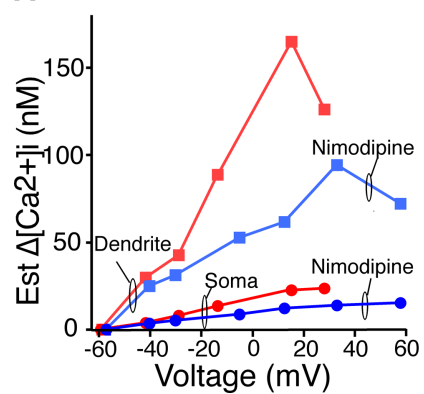

B

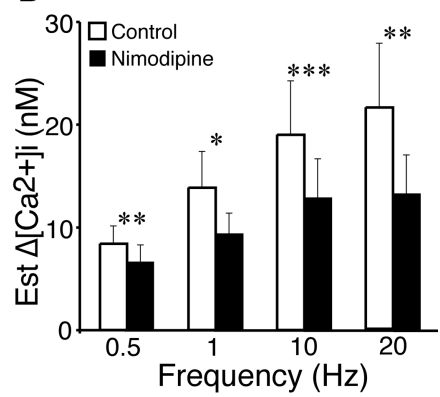

Figure 8. Action potential and membrane depolarization-induced $\left[\mathrm{Ca}^{2+}\right]_{\mathrm{i}}$ transients are attenuated by blocking L-type $\mathrm{Ca}^{2+}$ channels. $A$, Representative experiment showing the relationship of membrane voltage to $\Delta\left[\mathrm{Ca}^{2+}\right]_{\mathrm{i}}$ in the soma and dendrites of an SCN neuron depolarized (10-100 pA) for $200 \mathrm{~ms}$ in the presence of TTX $(0.5 \mu \mathrm{m})$. The L-type $\mathrm{Ca}^{2+}$ channel blocker nimodipine $(20 \mu \mathrm{m})$ reduced the $\Delta\left[\mathrm{Ca}^{2+}\right]_{\mathrm{i}} \sim 40 \%$. B, RHT-evoked action potentialinduced $\left[\mathrm{Ca}^{2+}\right]_{\mathrm{i}}$ transients were attenuated by nimodipine $(20 \mu \mathrm{M})$ in the presence of picrotoxin $(50 \mu \mathrm{M})$. Ten stimulus pulses were applied to the RHT at the frequencies indicated before and after nimodipine treatment. During RHT stimulation, occasional stimuli failed to evoke an action potential or a spontaneous action potential occurred; therefore, to facilitate comparisons between experiments, the $\Delta \mathrm{Ca}^{2+}$ was normalized (estimated $\Delta \mathrm{Ca}^{2+}=\Delta \mathrm{Ca}^{2+} / \# \mathrm{AP} \times$ 10). Nimodipine significantly reduced $\mathrm{Ca}^{2+}$ transients (mean with SEM) over a range of stimulus frequencies $\left(1-20 \mathrm{~Hz}, n=7\right.$ neurons; $0.5 \mathrm{~Hz}, n=6$ neurons; ${ }^{*} p \leq 0.05,{ }^{* *} p \leq 0.01$, ${ }^{* * *} p \leq 0.005$, paired $t$ test). Est., Estimated.

ously firing at $10 \mathrm{~Hz}$ receiving RHT input at $10 \mathrm{~Hz}$ would not appreciably increase. Therefore, we examined the magnitude of RHT-induced $\mathrm{Ca}^{2+}$ transients at different spontaneous action potential firing rates. Each neuron was hyperpolarized to eliminate spontaneous firing before receiving 10 RHT stimuli at $10 \mathrm{~Hz}$. The membrane potential was then depolarized to increase the spontaneous firing frequency. After stabilization of the firing rate and $\left[\mathrm{Ca}^{2+}\right]_{\mathrm{i}}$, the RHT was again stimulated (Fig. $10 \mathrm{~A}$ ). The magnitude of RHT-evoked $\mathrm{Ca}^{2+}$ transients as a percentage of control (no spontaneous firing) was inversely correlated $(r=-0.88 ; n=$ 11 neurons) with the spontaneous action potential firing rate (Fig. $10 \mathrm{~B}$ ). These data suggest that at a given light intensity, postsynaptic $\mathrm{Ca}^{2+}$ transients would be smaller in more depolarized neurons with faster action potential firing frequencies as occurs during the day and larger in more hyperpolarized neurons with slower firing rates as occurs at night.

\section{Discussion}

Environmental light intensity information is conveyed to the master circadian clock in the SCN by retinal ganglion cells that project glutamatergic fibers via the RHT to terminate on SCN neurons (Moore et al., 1995; Pu, 1999; Berson et al., 2002; Warren et al., 2003). Glutamate released from RHT terminals is proposed to activate NMDA receptors, which increases the $\left[\mathrm{Ca}^{2+}\right]_{\mathrm{i}}$ of SCN neurons (Kim and Dudek, 1991; Jiang et al., 1997; Colwell, 2001) and phase-shifts the circadian clock. In this model, $\mathrm{Ca}^{2+}$ activates intracellular biochemical pathways that alter the timing of "core" clock genes (Ding et al., 1994; Gillette, 1996; Pennartz et al., 2001; Cheng et al., 2004).

We investigated the mechanism by which glutamate released from RHT axon terminals increased the $\left[\mathrm{Ca}^{2+}\right]_{\mathrm{i}}$ in SCN neurons. Stimulation of the RHT sufficient to generate an EPSP did not produce detectable changes in $\left[\mathrm{Ca}^{2+}\right] \mathrm{i}$, whereas EPSP-induced action potentials evoked an increase in $\left[\mathrm{Ca}^{2+}\right]_{\mathrm{i}}$. The change in $\left[\mathrm{Ca}^{2+}\right]_{\mathrm{i}}$ was larger and decayed more quickly in the dendrites than in the soma, suggesting a compartmentalization of $\mathrm{Ca}^{2+}$ signaling in SCN neurons (Ikeda et al., 2003b). The magnitude of the $\mathrm{Ca}^{2+}$ response was dependent on the RHT stimulation fre-
A
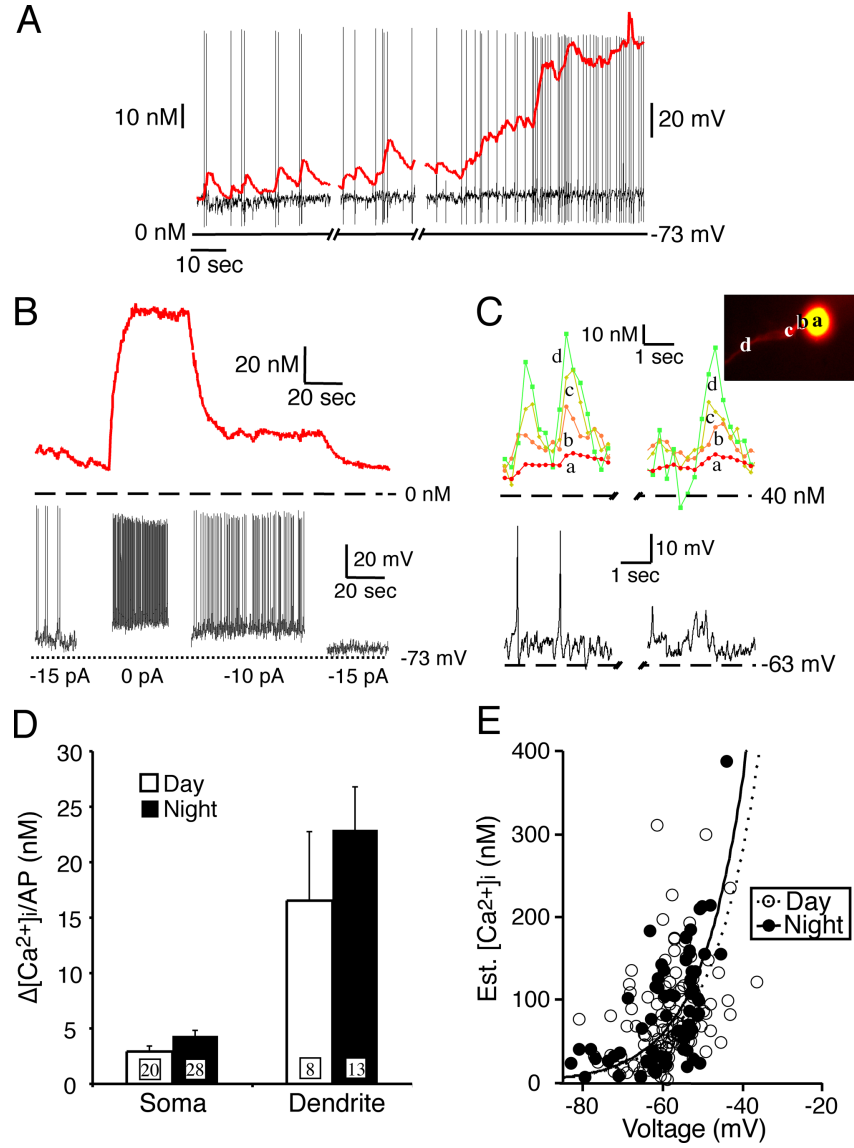

Figure 9. Spontaneous action potentials and $\left[\mathrm{Ca}^{2+}\right]_{\mathrm{i}}$ in the soma and dendrites. $\boldsymbol{A}$, Example of the temporal relationship between $\left[\mathrm{Ca}^{2+}\right]_{i}$ and spontaneous action potentials in a SCN neuron. $\boldsymbol{B}$, Changing the membrane potential modified the $\left[\mathrm{Ca}^{2+}\right]_{i}$ in parallel with changes of the action potential frequency. With each change in membrane potential, the $\left[\mathrm{Ca}^{2+}\right]_{i}$ reaches a new steady-state level within a few seconds. $\boldsymbol{C}$, Spontaneous action potentials generated larger $\left[\mathrm{Ca}^{2+}\right]_{\mathrm{i}}$ changes in the distal dendrites than in the soma. Dendritic $\left[\mathrm{Ca}^{2+}\right]_{\mathrm{i}}$ returned to baseline, whereas the somatic $\left[\mathrm{Ca}^{2+}\right]_{i}$ showed summation between action potentials. Prolonged spontaneous depolarization with and without an action potential had a similar temporal and regional $\left[\mathrm{Ca}^{2+}\right]_{i}$ response. $\boldsymbol{D}$, The rise in $\left[\mathrm{Ca}^{2+}\right]_{i}$ evoked by a single spontaneous action potential was much larger in the dendrities than in the soma. The $\mathrm{Ca}^{2+}$ response (mean with SEM, numbers of neurons are in the boxes) from single action potentials did not differ significantly between day and night in either the soma or dendrites. $\boldsymbol{E},\left[\mathrm{Ca}^{2+}\right]_{\mathrm{i}}$ increased exponentially with increased membrane potential in both day and night neurons. Plateau $\mathrm{Ca}^{2+}$ responses were recorded along with corresponding baseline voltage measurements at various levels of applied current. Most neurons with a membrane potential between -65 and $-55 \mathrm{mV}$ had a corresponding $\left[\mathrm{Ca}^{2+}\right]_{\mathrm{i}}$ between 50 and $150 \mathrm{~nm}$.

quency and duration and on the $\mathrm{SCN}$ neuron spontaneous action potential frequency. The changes in $\left[\mathrm{Ca}^{2+}\right]_{\mathrm{i}}$ were attenuated by blocking L-type $\mathrm{Ca}^{2+}$ channels. We conclude that synaptically activated glutamate receptors increase postsynaptic somatic $\left[\mathrm{Ca}^{2+}\right]_{\mathrm{i}}$ by generating action potentials and activating voltagedependent $\mathrm{Ca}^{2+}$ channels.

Light-sensitive retinal ganglion cells fire action potentials at frequencies contingent on the light intensity (brighter light faster action potential frequencies) and throughout the period of light exposure (Berson et al., 2002; Warren et al., 2003; Tu et al., 2005). RHT stimulation over similar frequency ranges was used to evoke $\mathrm{Ca}^{2+}$ transients in $\mathrm{SCN}$ neurons. The magnitude of the $\mathrm{Ca}^{2+}$ response induced by RHT stimulation was dependent on the frequency and duration of stimulation. When SCN neurons fire spontaneous action potentials at slow frequencies, RHT stimulation evoked a similar rise in $\left[\mathrm{Ca}^{2+}\right]_{\mathrm{i}}$ during the day and night. 


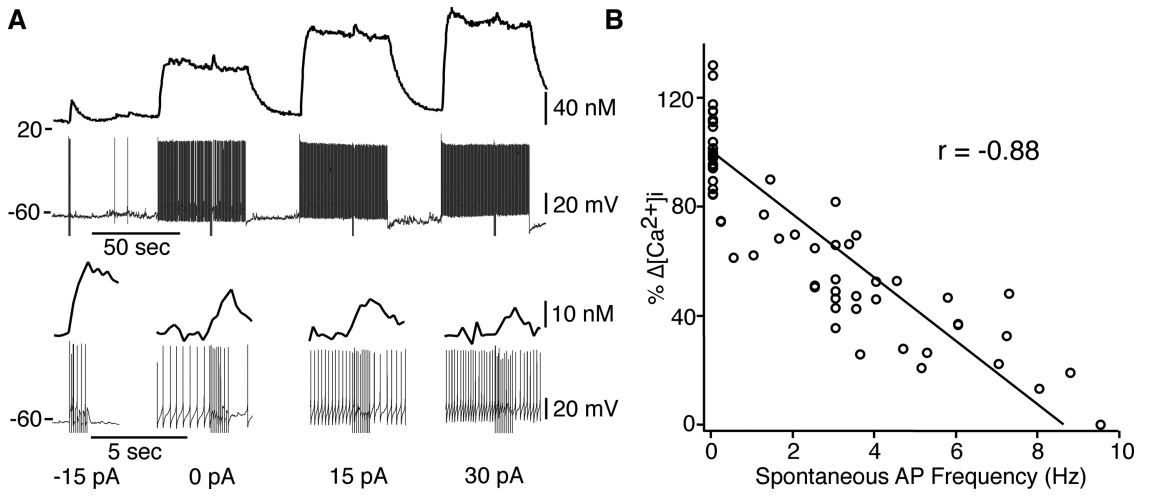

Figure 10. The magnitude of RHT-evoked $\left[\mathrm{Ca}^{2+}\right]_{\mathrm{i}}$ transients was inversely correlated with the spontaneous action potential firing rate. $A$, An SCN neuron recorded during the day showing decreasing $\mathrm{Ca}^{2+}$ responses to $10 \mathrm{RHT}$ stimuli $(10 \mathrm{~Hz})$ with increasing frequency of spontaneous action potential firing. The top traces show the $\left[\mathrm{Ca}^{2+}\right]_{\mathrm{i}}$ and membrane potential, and the bottom traces are an expanded scale showing the evoked change in $\mathrm{Ca}^{2+}$ and RHT stimuli. The neuron was hyperpolarized to inhibit spontaneous action potentials. Small current steps were used to depolarize the membrane and induce action potential firing. Each current step evoked a new steady-state $\left[\mathrm{Ca}^{2+}\right]_{\mathrm{i}}$ and an associated change in action potential firing rate. A return to the original membrane potential terminated action potential firing and was followed by recovery of $\left[\mathrm{Ca}^{2+}\right]_{\mathrm{i}}$. Membrane depolarization increased the frequency of action potentials and lowered the magnitude of the RHT-evoked $\mathrm{Ca}^{2+}$ transient. $\boldsymbol{B}$, Evoked $\left[\mathrm{Ca}^{2+}\right]_{\mathrm{i}}$ transients were inversely correlated with the spontaneous action potential (AP) firing frequency $\left(r^{2}=0.78\right.$; $n=11$ neurons). Data represent the percentage change in normalized $\mathrm{Ca}^{2+}$ transients evoked by RHT stimulation (10 stimuli at $10 \mathrm{~Hz}$ ) when no spontaneous action potentials were firing compared with those evoked in the presence of action potentials firing at the indicated frequencies.

We compared the frequency and duration of RHT stimulation (10 or 50 stimuli) on $\left[\mathrm{Ca}^{2+}\right]_{\mathrm{i}}$ and the number of evoked action potentials. During low-frequency $(\leq 1 \mathrm{~Hz})$ stimulation, $\left[\mathrm{Ca}^{2+}\right]_{\mathrm{i}}$ reached a plateau in both the soma and dendrites. Highfrequency $(\geq 5 \mathrm{~Hz})$ stimulation produced large $\mathrm{Ca}^{2+}$ transients that did not plateau within the 10 or 50 stimuli. These data indicate that when SCN neurons are similarly hyperpolarized to low action potential frequencies, the change in postsynaptic $\left[\mathrm{Ca}^{2+}\right]_{i}$ was related to the frequency and duration of the excitatory RHT input.

$\mathrm{Ca}^{2+}$ responses evoked by RHT stimulation or membrane depolarization were larger in amplitude and faster to decay in the dendrites compared with the soma, similar to observations in hippocampal pyramidal neurons (Jaffe et al., 1994; Christie et al., 1995). Small injections of current that approximated an EPSP $(5-10 \mathrm{mV})$ resulted in little or no elevation of somatic $\left[\mathrm{Ca}^{2+}\right]_{\mathrm{i}}$, whereas larger current injections emulating an action potential increased $\left[\mathrm{Ca}^{2+}\right]_{\mathrm{i}}$. Increasing the magnitude of membrane depolarization produced $\mathrm{Ca}^{2+}$ transients with a maximum between 0 and $+40 \mathrm{mV}$. Similar relationships between $\left[\mathrm{Ca}^{2+}\right]_{\mathrm{i}}$ and voltage occur in dorsal root ganglion (Thayer and Miller, 1990) and visual interneurons (Durr and Egelhaaf, 1999). Increasing the duration of membrane depolarization increased the ratio of $\left[\mathrm{Ca}^{2+}\right]_{i}$ in the soma compared with the dendrite. These data suggest that an increase in somatic $\left[\mathrm{Ca}^{2+}\right]_{\mathrm{i}}$ requires a larger and longer excitatory input than required to increase dendritic $\left[\mathrm{Ca}^{2+}\right]_{\mathrm{i}}$. These differences may reflect differences in the volume and geometry of the cellular compartments, variance in $\mathrm{Ca}^{2+}$ buffering capability, and diversity of voltage-dependent channel expression.

Spontaneous and evoked action potential firing increased $\left[\mathrm{Ca}^{2+}\right]_{\mathrm{i}}$ in SCN neurons. During an action potential, a significant $\mathrm{Ca}^{2+}$ current flows into SCN neurons (Jackson et al., 2004). During slow frequency firing, an isolated spontaneous action potential evoked a rise in $\mathrm{Ca}^{2+} \sim 3 \mathrm{~nm}$ in the soma, which did not differ significantly between day and night phases. A slow firing rate allowed time for $\left[\mathrm{Ca}^{2+}\right]_{\mathrm{i}}$ to decay back to baseline levels, whereas a rapid train of action potentials resulted in a stepwise increase in
$\left[\mathrm{Ca}^{2+}\right]_{\mathrm{i}}$. TTX application blocked action potential firing and lowered $\left[\mathrm{Ca}^{2+}\right]_{\mathrm{i}}$ (Fig. $6 \mathrm{~B})$. The relationship between $\left[\mathrm{Ca}^{2+}\right]_{\mathrm{i}}$ and membrane potential in both day and night neurons had a sharp inflection near -60 $\mathrm{mV}$ (Fig. 9E), consistent with activation of voltage-dependent $\mathrm{Ca}^{2+}$ channels. SCN neuronal conductance (Jiang et al., 1997), membrane potential (de Jeu et al., 1998), firing frequency (Jobst and Allen, 2002; Pennartz et al., 2002; Pitts et al., 2006), and $\left[\mathrm{Ca}^{2+}\right]_{\mathrm{i}}$ (Colwell, 2000; Ikeda, 2004) are higher in SCN neurons during the day than at night. We observed that RHT-evoked $\mathrm{Ca}^{2+}$ transients were inversely correlated with the spontaneous firing frequency. The relationship between $\left[\mathrm{Ca}^{2+}\right]_{i}$ and RHT stimulation frequency (Fig. 3), predicts that the incremental change in $\mathrm{Ca}^{2+}$ would be smaller with increasing firing frequency. For example, the $\left[\mathrm{Ca}^{2+}\right]_{\mathrm{i}}$ of a SCN neuron spontaneously firing at $10 \mathrm{~Hz}$ would not be appreciably increased by RHT input at 10 $\mathrm{Hz}$. Therefore, $\mathrm{Ca}^{2+}$ responses of SCN neurons with similar spontaneous firing frequencies to RHT input during day and night were similar. Although the regulation of $\left[\mathrm{Ca}^{2+}\right]_{\mathrm{i}}$ is likely multifactorial (e.g., intracellular stores, $\mathrm{Ca}^{2+}$ channels, $\mathrm{Ca}^{2+}$ pumps, etc.), voltage-dependent events such as the resting membrane potential and spontaneous and synaptically evoked action potential firing are important components of the overall $\left[\mathrm{Ca}^{2+}\right]_{\mathrm{i}}$. These data suggest that light-induced phase advances and delays may be initiated by evoking postsynaptic $\mathrm{Ca}^{2+}$ transients at times of relative membrane hyperpolarization and slow spontaneous action potential firing as occurs at night.

The L-type $\mathrm{Ca}^{2+}$ channel blocker nimodipine reduced the amplitude of RHT stimulation-induced $\mathrm{Ca}^{2+}$ transients $21-39 \%$ over a range of frequencies in the soma and membrane depolarization-induced $\mathrm{Ca}^{2+}$ transients approximately $\sim 40 \%$ in both the soma and dendrites. Nimodipine did not lower resting $\left[\mathrm{Ca}^{2+}\right]_{\mathrm{i}}$, consistent with intracellular $\mathrm{Ca}^{2+}$ stores having a major role in the regulation of baseline $\mathrm{Ca}^{2+}$ circadian oscillations (Ikeda, 2004). In hippocampal neurons, a similar (33\%) reduction in spike-induced $\mathrm{Ca}^{2+}$ influx was observed in the soma, but a lower percentage was observed in distant $(50-200 \mu \mathrm{m})$ processes (Christie et al., 1995). Experiments using blockers of other voltage-gated $\mathrm{Ca}^{2+}$ channels were not preformed because, unlike L-type channels, these channels are heavily expressed on RHT axon terminals (Moldavan et al., 2006). L-type $\mathrm{Ca}^{2+}$ channels in rat SCN contribute to the generation of spontaneous oscillations during the day (Pennartz et al., 2002; Jackson et al., 2004) and have a higher relative level of expression over other voltagedependent $\mathrm{Ca}^{2+}$ channels (Nahm et al., 2005), but the neuronal distribution is not known. Pituitary adenylate cyclase-activating polypeptide (PACAP) potentiation of $\mathrm{K}^{+}$- and glutamateevoked $\mathrm{Ca}^{2+}$ transients in SCN neurons are blocked by nimodipine, suggesting that L-type $\mathrm{Ca}^{2+}$ channels contribute to the regulation of the circadian clock by PACAP (Dziema and Obrietan, 2002). Nimodipine inhibits glutamate-induced phase advances (Kim et al., 2005) and potentiates light-induced phase shifts in mice (Benloucif et al., 2003). These data suggest that L-type $\mathrm{Ca}^{2+}$ channels mediate a significant proportion of depolarization- 
induced $\mathrm{Ca}^{2+}$ transients and are an important component of the light-signaling pathway.

Glutamate receptor activation elevates $\left[\mathrm{Ca}^{2+}\right]_{\mathrm{i}}$ in the SCN via influx through AMPA (Michel et al., 2002; Ikeda et al., 2003a) and NMDA (Colwell, 2001; Ikeda et al., 2003a) receptors and phaseshifts the circadian clock (Colwell and Menaker, 1992; Ding et al., 1994; Kim et al., 2005). We found that exogenous glutamate treatment produced a large $\mathrm{Ca}^{2+}$ transient but the glutamate released from RHT terminals induced EPSPs without measurably changing somatic $\left[\mathrm{Ca}^{2+}\right]_{\mathrm{i}}$. In hippocampal pyramidal neurons, synaptically mediated $\left[\mathrm{Ca}^{2+}\right]_{i}$ changes are tightly regulated in time and space because EPSP-evoked $\mathrm{Ca}^{2+}$ transients are restricted to the spine head (Koester and Sakmann, 1998). Our data demonstrate that EPSPs evoked by glutamate released from RHT axon terminals that did not evoke an action potential did not change somatic $\left[\mathrm{Ca}^{2+}\right]_{\mathrm{i}}$ and suggests that only a fraction of SCN glutamate receptors are used under normal physiological conditions.

The data presented above suggest a model in which the magnitude and duration of changes in SCN neuronal $\left[\mathrm{Ca}^{2+}\right]_{\mathrm{i}}$ induced by glutamate released from RHT axon terminals is the result of membrane depolarization activating action potentials and opening voltage-dependent $\mathrm{Ca}^{2+}$ channels and depend on the spontaneous action potential frequency. Block et al. (1996), in a series of studies using Bulla, demonstrated that the circadian clock can be shifted by membrane depolarization or other manipulations that increase $\left[\mathrm{Ca}^{2+}\right]_{\mathrm{i}}$. Hyperpolarizing the membrane potential or otherwise blocking the increase in $\left[\mathrm{Ca}^{2+}\right]_{\mathrm{i}}$ prevents phase shifts. Although the underlying mechanism for light synchronization of the SCN rhythm is not yet fully elucidated, our data suggest that for $\mathrm{Ca}^{2+}$ to act as a second messenger to induce phase advances or delays, light-induced signaling from retinal ganglion cells must augment the underlying oscillatory change in somatic $\left[\mathrm{Ca}^{2+}\right]_{\mathrm{i}}$ by evoking postsynaptic action potentials in SCN neurons during a period of slow spontaneous firing and relative hyperpolarization as occurs at night.

\section{References}

Benloucif S, Masana MI, Zee PC, Dubocovich ML (2003) Nimodipine potentiates light-induced phase shifts of circadian activity rhythms but not c-fos expression in the suprachiasmatic nucleus of mice. Brain Res 966:157-161.

Berson DM, Dunn FA, Takao M (2002) Phototransduction by retinal ganglion cells that set the circadian clock. Science 295:1070-1073.

Block GD, Geusz M, Khalsa SB, Michel S, Whitmore D (1996) Circadian rhythm generation, expression and entrainment in a molluscan model system. Prog Brain Res 111:93-102.

Cahill GM, Menaker M (1989) Effects of excitatory amino acid receptor antagonists and agonists on suprachiasmatic nucleus responses to retinohypothalamic tract volleys. Brain Res 479:76-82.

Castel M, Belenky M, Cohen S, Ottersen OP, Storm-Mathisen J (1993) Glutamate-like immunoreactivity in retinal terminals of the mouse suprachiasmatic nucleus. Eur J Neurosci 5:368-381.

Cheng HY, Obrietan K, Cain SW, Lee BY, Agostino PV, Joza NA, Harrington ME, Ralph MR, Penninger JM (2004) Dexras1 potentiates photic and suppresses nonphotic responses of the circadian clock. Neuron 43:715-728.

Christie BR, Eliot LS, Ito K, Miyakawa H, Johnston D (1995) Different $\mathrm{Ca} 2+$ channels in soma and dendrites of hippocampal pyramidal neurons mediate spike-induced Ca2+ influx. J Neurophysiol 73:2553-2557.

Colwell CS (2000) Circadian modulation of calcium levels in cells in the suprachiasmatic nucleus. Eur J Neurosci 12:571-576.

Colwell CS (2001) NMDA-evoked calcium transients and currents in the suprachiasmatic nucleus: gating by the circadian system. Eur J Neurosci 13:1420-1428.

Colwell CS, Menaker M (1992) NMDA as well as non-NMDA receptor an- tagonists can prevent the phase-shifting effects of light on the circadian system of the golden hamster. J Biol Rhythms 7:125-136.

DeCoursey PJ, Krulas JR, Mele G, Holley DC (1997) Circadian performance of suprachiasmatic nuclei ( $\mathrm{SCN}$ )-lesioned antelope ground squirrels in a desert enclosure. Physiol Behav 62:1099-1108.

de Jeu M, Hermes M, Pennartz C (1998) Circadian modulation of membrane properties in slices of rat suprachiasmatic nucleus. NeuroReport 9:3725-3729.

Ding JM, Chen D, Weber ET, Faiman LE, Rea MA, Gillette MU (1994) Resetting the biological clock: mediation of nocturnal circadian shifts by glutamate and NO. Science 266:1713-1717.

Ding JM, Faiman LE, Hurst WJ, Kuriashkina LR, Gillette MU (1997) Resetting the biological clock: mediation of nocturnal CREB phosphorylation via light, glutamate, and nitric oxide. J Neurosci 17:667-675.

Ding JM, Buchanan GF, Tischkau SA, Chen D, Kuriashkina L, Faiman LE, Alster JM, McPherson PS, Campbell KP, Gillette MU (1998) A neuronal ryanodine receptor mediates light-induced phase delays of the circadian clock. Nature 394:381-384.

Durr V, Egelhaaf M (1999) In vivo calcium accumulation in presynaptic and postsynaptic dendrites of visual interneurons. J Neurophysiol 82:3327-3338.

Dziema H, Obrietan K (2002) PACAP potentiates L-type calcium channel conductance in suprachiasmatic nucleus neurons by activating the MAPK pathway. J Neurophysiol 88:1374-1386.

Gillette MU (1996) Regulation of entrainment pathways by the suprachiasmatic circadian clock: sensitivities to second messengers. Prog Brain Res 111:121-132.

Grynkiewicz G, Poenie M, Tsien RY (1985) A new generation of Ca2+ indicators with greatly improved fluorescence properties. J Biol Chem 260:3440-3450.

Ikeda M (2004) Calcium dynamics and circadian rhythms in suprachiasmatic nucleus neurons. Neuroscientist 10:315-324.

Ikeda M, Yoshioka T, Allen CN (2003a) Developmental and circadian changes in $\mathrm{Ca} 2+$ mobilization mediated by GABAA and NMDA receptors in the suprachiasmatic nucleus. Eur J Neurosci 17:58-70.

Ikeda M, Sugiyama T, Wallace CS, Gompf HS, Yoshioka T, Miyawaki A, Allen CN (2003b) Circadian dynamics of cytosolic and nuclear Ca2 + in single suprachiasmatic nucleus neurons. Neuron 38:253-263.

Inouye ST, Kawamura H (1979) Persistence of circadian rhythmicity in a mammalian hypothalamic "island" containing the suprachiasmatic nucleus. Proc Natl Acad Sci USA 76:5962-5966.

Jackson AC, Yao GL, Bean BP (2004) Mechanism of spontaneous firing in dorsomedial suprachiasmatic nucleus neurons. J Neurosci 24:7985-7998.

Jaffe DB, Ross WN, Lisman JE, Lasser-Ross N, Miyakawa H, Johnston D (1994) A model for dendritic Ca2 + accumulation in hippocampal pyramidal neurons based on fluorescence imaging measurements. J Neurophysiol 71:1065-1077.

Jiang ZG, Yang Y, Liu ZP, Allen CN (1997) Membrane properties and synaptic inputs of suprachiasmatic nucleus neurons in rat brain slices. J Physiol (Lond) 499:141-159.

Jobst EE, Allen CN (2002) Calbindin neurons in the hamster suprachiasmatic nucleus do not exhibit a circadian variation in spontaneous firing rate. Eur J Neurosci 16:2469-2474.

Kim DY, Choi HJ, Kim JS, Kim YS, Jeong DU, Shin HC, Kim MJ, Han HC, Hong SK, Kim YI (2005) Voltage-gated calcium channels play crucial roles in the glutamate-induced phase shifts of the rat suprachiasmatic circadian clock. Eur J Neurosci 21:1215-1222.

Kim YI, Dudek FE (1991) Intracellular electrophysiological study of suprachiasmatic nucleus neurons in rodents: excitatory synaptic mechanisms. J Physiol (Lond) 444:269-287.

Kim YI, Dudek FE (1993) Membrane properties of rat suprachiasmatic nucleus neurons receiving optic nerve input. J Physiol (Lond) 464:229-243.

Koester HJ, Sakmann B (1998) Calcium dynamics in single spines during coincident pre- and postsynaptic activity depend on relative timing of back-propagating action potentials and subthreshold excitatory postsynaptic potentials. Proc Natl Acad Sci USA 95:9596-9601.

Lundkvist GB, Kwak Y, Davis EK, Tei H, Block GD (2005) A calcium flux is required for circadian rhythm generation in mammalian pacemaker neurons. J Neurosci 25:7682-7686.

Michel S, Itri J, Colwell CS (2002) Excitatory mechanisms in the suprachiasmatic nucleus: the role of AMPA/KA glutamate receptors. J Neurophysiol 88:817-828. 
Moldavan MG, Irwin RP, Allen CN (2006) Presynaptic GABA(B) receptors regulate retinohypothalamic tract synaptic transmission by inhibiting voltage-gated Ca2 + channels. J Neurophysiol 95:3727-3741.

Moore RY, Eichler VB (1972) Loss of circadian adrenal corticosterone rhythm following suprachiasmatic nucleus lesions in the rat. Brain Res Brain Res Rev 42:201-206.

Moore RY, Speh JC, Card JP (1995) The retinohypothalamic tract originates from a distinct subset of retinal ganglion cells. J Comp Neurol 352:351-366.

Nahm SS, Farnell YZ, Griffith W, Earnest DJ (2005) Circadian regulation and function of voltage-dependent calcium channels in the suprachiasmatic nucleus. J Neurosci 25:9304-9308.

Ouyang Y, Andersson CR, Kindo T, Golden SS, Johnson CH (1998) Resonating circadian clocks enhance fitness in cyanobacteria. Proc Natl Acad Sci USA 95:8660-8664.

Pennartz CM, Hamstra R, Geurtsen AM (2001) Enhanced NMDA receptor activity in retinal inputs to the rat suprachiasmatic nucleus during the subjective night. J Physiol (Lond) 532:181-194.

Pennartz CM, de Jeu MT, Bos NP, Schaap J, Geurtsen AM (2002) Diurnal modulation of pacemaker potentials and calcium current in the mammalian circadian clock. Nature 416:286-290.

Pitts GR, Ohta H, McMahon DG (2006) Daily rhythmicity of large- conductance $\mathrm{Ca} 2+$-activated $\mathrm{K}+$ currents in suprachiasmatic nucleus neurons. Brain Res 1071:54-62.

Pu M (1999) Dendritic morphology of cat retinal ganglion cells projecting to suprachiasmatic nucleus. J Comp Neurol 414:267-274.

Shirakawa T, Moore RY (1994) Glutamate shifts the phase of the circadian neuronal firing rhythm in the rat suprachiasmatic nucleus in vitro. Neurosci Lett 178:47-50.

Stephan FK, Zucker I (1972) Circadian rhythms in drinking behavior and locomotor activity of rats are eliminated by hypothalamic lesions. Proc Natl Acad Sci USA 69:1583-1586.

Thayer SA, Miller RJ (1990) Regulation of the intracellular free calcium concentration in single rat dorsal root ganglion neurones in vitro. J Physiol (Lond) 425:85-115.

Tu DC, Zhang D, Demas J, Slutsky EB, Provencio I, Holy TE, Van Gelder RN (2005) Physiologic diversity and development of intrinsically photosensitive retinal ganglion cells. Neuron 48:987-999.

Warren EJ, Allen CN, Brown RL, Robinson DW (2003) Intrinsic light responses of retinal ganglion cells projecting to the circadian system. Eur J Neurosci 17:1727-1735.

Yuste R (2000) Loading brain slices with AM esters of calcium indicators. In: Imaging neurons: a laboratory manual (Yuste R, Lanni F, Konnerth A, eds), pp 34.31-34.39. Woodbury, NY: Cold Spring Harbor Laboratory. 